\title{
Invariant V $\alpha 14$ Natural Killer T Cell Activation by Edible Mushroom Acidic Glycosphingolipids
}

\author{
Hirofumi Nozaki,${ }^{a, 1)}$ Saki ITonori,${ }^{b}$ Mutsumi Sugita, ${ }^{b}$ Kimihide Nakamura,${ }^{c}$ Kiyoshi Ohba,${ }^{d}$ \\ Masao OHnishi, ${ }^{a}$ Kunitoshi Imai, ${ }^{e}$ Yasuyuki IGarashi,${ }^{f}$ Akemi Suzuki, ${ }^{g}$ and Yasunori Kushi ${ }^{*}, a$ \\ ${ }^{a}$ Department of Food Science, Obihiro University of Agriculture and Veterinary Medicine; ${ }^{c}$ Health Care Administration \\ Center, Obihiro University of Agriculture and Veterinary Medicine; ${ }^{e}$ Research Center for Animal Hygiene and Food Safety, \\ Obihiro University of Agriculture and Veterinary Medicine; Obihiro, Hokkaido 080-8555, Japan: ${ }^{b}$ Department of \\ Chemistry, Faculty of Liberal Arts and Education, Shiga University; Otsu, Shiga 520-0862, Japan: ${ }^{d}$ Hokkaido Tokachi \\ Area Regional Food Processing Technology Center; Obihiro, Hokkaido 080-2462, Japan: ${ }^{f}$ Laboratory of Biomembrane \\ and Biofunctional Chemistry, Graduate School of Pharmaceutical Sciences, Hokkaido University; Sapporo, Hokkaido \\ 060-0812, Japan: and ${ }^{g}$ Institute of Glycoscience, Tokai University; Hiratsuka, Kanagawa 259-1292, Japan.
}

Received December 9, 2009; accepted January 18, 2010; published online January 20, 2010

Invariant natural killer $\mathrm{T}$ ( $i \mathrm{NKT}$ ) cells regulate multi-immune response through $\mathrm{Th} 1 / \mathrm{Th} 2$ cytokine release triggered by the recognition of CD1d-restricted glycosphingolipid antigens. Here we report that acidic glycosphingolipids (AGLs) of mushroom (Hypsizigus marmoreus and Pleurotus eryngii) presented by murine CD1dtransfected rat basophilic leukocytes induced interleukin-2 (IL-2) release from $i$ NKT hybridoma cells. AGL-1, one of the AGLs, containing mannose at the non-reducing ends, induced CD1d-dependent IL-2 release. Although $\alpha$-galactosylceramide ( $\alpha$-GalCer) presented by CD11c-positive cells induced both interferon- $\gamma$ (IFN- $\gamma$ ) and IL-4 release, all of AGLs presented by CD11c-positive cells and AGL-1 presented by B cells induced IL-4 release from $i$ NKT hybridoma cells. A single intravenous injection of AGLs into B6 mice induced only a little elevation of IL-4 in serum but repeated intravenous injection of AGLs induced prolonged retention of IL-4 in serum; therefore, these results suggested that edible mushroom AGLs might contribute to the retention of immunohomeostasis through the minimum induction of $i \mathrm{NKT}$ cell activation in vivo.

Key words alpha-galactosylceramide; glycosphingolipid; edible mushroom; natural killer T cell; mouse

Natural killer T (NKT) cells recognize CD1d loaded with glycosphingolipid (GSL) antigens. After being stimulated by GSL antigens, NKT cells immediately secrete cytokines. ${ }^{2-4)}$ The variety of cytokines release from NKT cells can promote immunoresponses against tumors and microbial infections, and regulate autoimmune responses, ${ }^{5,6)}$ although a puzzling aspect of these responses is that both Th1 and Th2 cytokines can be secreted in response to the stimulation.

The fungal glycolipids are exogenous antigens for NKT cells $^{7}$; therefore, we focused on acidic glycosphingolipids (AGLs) of edible mushrooms (Hypsizigus marmoreus and Pleurotus eryngii) ${ }^{8,9)}$ and reported that AGLs induced interferon- $\gamma($ IFN- $\gamma$ ) and interleukin-4 (IL-4) release from murine $\mathrm{T}$ cells in a CD11c-positive cell-dependent manner. ${ }^{10)}$

Invariant natural killer $\mathrm{T}(\mathrm{iNKT})$ cells, that are more than $80 \%$ of murine NKT cells, express an invariant T cell receptor $\mathrm{V} \alpha 14$ chain in combination with certain $\mathrm{V} \beta$ chains. In mice, CD1d-dependent NKT cells are either CD4CD8double negative or CD4-positive. The significance of CD4 expression on NKT cells is ambiguous because there is no evidence of any interaction between CD4 and MHC class II molecules on antigen-presenting cells (APCs), although CD4 can directly interacts with CD1d and enhances NKT cell activation. ${ }^{11)}$ Additionally, NKT cells mainly leave the thymus when NK1.1 is negative. ${ }^{6}$ )

In this study, we reported that edible mushroom AGLs activated CD4-positive NK1.1-negative $i$ NKT hybridoma cells that express $\mathrm{V} \alpha 14-\mathrm{J} \alpha 18 / \mathrm{V} \beta 8.2^{12}$ in a CD1d-dependent manner and intravenous AGL injection elevated the cytokine level.

\section{MATERIALS AND METHODS}

Materials Purified AGLs of H. marmoreus and P. eryngii were structurally elucidated according to previous reports, as described briefly. ${ }^{10,13)}$ Saponified and dialyzed extracts were fractionated on a DEAE-Sephadex A-25 column (acetate form) (Amersham Biosciences AB, Uppsala, Sweden), and further purification was performed using a silica gel6RS-8060 Iatrobeads column (Iatron Laboratories Inc., Tokyo, Japan). The composition of fatty acids and sugars, identification of phosphate bonds, confirmation of inositolphosphate content, determination of linkages among sugars and between sugar and inositol in purified AGLs, and AGL purity was confirmed by treatment with the appropriate reagents and using assays including columns, thin layer chromatography, a microwave oven, gas chromatography, gas-liquid chromatography/mass spectrometry, matrix-assisted laser desorption ionization-time of flight/mass spectrometry and ${ }^{1} \mathrm{H}$ NMR. $\alpha$-Galactosylceramide ( $\alpha$-GalCer) (KRN7000: ALX306-027) and isoglobotrihexosylceramide (iGb3) (ALX-306028) were purchased from ALEXIS Biochemicals (Lausanne, Switzerland).

Mice and Protocols for in Vivo Experiments AGLs were dissolved in $100 \%$ polysorbate-20, diluted with sterilized phosphate buffered saline (PBS) to $0.5 \%$ polysorbate20 , and then kept at $4{ }^{\circ} \mathrm{C}$ until used. Stock solutions were further diluted to 200 and $100 \mu \mathrm{g} / \mathrm{ml}$ AGL or $5 \mu \mathrm{g} / \mathrm{ml} \alpha$-GalCer in PBS containing $0.025 \%$ polysorbate- 20 just before injection. PBS containing $0.025 \%$ polysorbate- 20 was used in all experiments as the control solution. C57BL/6 mice (Charles River Laboratories Japan Inc., Yokohama, Japan), maintained under specific pathogen-free conditions in accordance with 
institutional guidelines (Obihiro Univ. of Agri. \& Vet. Med.), were injected in the tail vein with $100 \mu \mathrm{l}$ vehicle solution containing $0.5 \mu \mathrm{g} \alpha$-GalCer, $20 \mu \mathrm{g}$ AGL or $10 \mu \mathrm{g}$ AGL. To investigate the effect of repeated challenge $(10 \mu \mathrm{g} \times 2)$, mice were injected in the tail vein with $100 \mu$ l vehicle solution containing $10 \mu \mathrm{g}$ AGL and were injected again $24 \mathrm{~h}$ later after the first injection. All serum samples were obtained and kept at $-20{ }^{\circ} \mathrm{C}$ until used. IFN- $\gamma$ and IL-4 levels were measured by ELISA (Becton, Dickinson and Co., NJ, U.S.A.).

Protocols for in Vitro Experiments To prepare mononuclear cell (MNC) from a single cell suspension, total splenocytes and thymocytes pooled from naive C57BL/6 mice were applied to density gradient centrifugation, NycoPrep (AXIS-SHIELD, Oslo, Norway). To isolate splenic and thymic CD11c-positive cells, labeled MNCs with CD11c MicroBeads (Miltenyi Biotec, Gladbach, Germany) were applied to MACS (Miltenyi Biotec), respectively. To isolate $\mathrm{B}$ cells, collected CD11c-negative splenocytes were labeled with goat anti-mouse immunoglobulin G (IgG) MicroBeads (Miltenyi Biotec) and were applied to MACS again. These sorted cells, $i$ NKT hybridoma cells (1B6, kindly provided by Dr. Kazunori Onoè, Univ. of Hokkaido) ${ }^{12)}$ and both murine CD1d-transfected rat basophilic leukocytes (RBL-CD1d) and rat basophilic leukocytes (RBL) (kindly provided by Dr. Albert Bendelac, Univ. of Chicago) as $\mathrm{APCs}^{14)}$ were cultured in ME1640 (RPMI 1640 containing $50 \mu \mathrm{M}$ 2-mercaptoethanol, $1 \mathrm{~mm}$ pyruvate, $0.1 \mathrm{~mm}$ non-essential amino acids, $100 \mathrm{U} / \mathrm{ml}$ penicillin, $100 \mu \mathrm{g} / \mathrm{ml}$ streptomycin, $100 \mu \mathrm{g} / \mathrm{ml}$ kanamycin and $10 \%$ fetal bovine serum) containing $0.5 \%$ dimethyl sulfoxide (DMSO).

GSLs were dissolved in $100 \%$ DMSO and kept at $4{ }^{\circ} \mathrm{C}$ until used. Sonicated stock solutions were further diluted with ME1640 to $5 \mu \mathrm{g} / \mathrm{ml}$ GSL, $0.5 \%$ DMSO. ME1640 containing $0.5 \%$ DMSO was used in all experiments as the control solution. $2 \times 10^{5} i$ NKT cells with $5 \times 10^{4}$ APCs were cultured for $48 \mathrm{~h}$ at $37^{\circ} \mathrm{C}$ in $5 \% \mathrm{CO}_{2}$ in 96-well flat-bottom plates in the presence of GSL antigens or not. After incubation, supernatants of parallel cultures were collected and the concentrations of IFN- $\gamma$, IL- 2 and IL- 4 were measured by ELISA (Becton, Dickinson and Co.).

\section{RESULTS}

Edible Mushroom AGLs Induce Cytokine Release from Murine $i$ NKT Hybridoma Cells in a CD1d-Dependent Manner in Vitro Total AGLs of $H$. marmoreus (represented as T-H.m) were composed of AGL-1 [Man- $\alpha 1$,2-InsP-Cer, represented as AGL-1H], AGL-4 [Gal- $\alpha 1,3$ (Fuc$\alpha 1,2)$-Gal- $\beta 1,6-\mathrm{Man}-\alpha 1,2-$ Ins-P-Cer] and AGL-6 [Gal$\alpha 1,2-G a 1-\alpha 1,2-G a l-\alpha 1,3$ (Fuc- $\alpha 1,2)$-Gal- $\beta 1,6-$ Man- $\alpha 1,2-$ Ins-P-Cer], while that of $P$. eryngii (represented as T-P.e) were composed of AGL-1 (represented as AGL-1P) and AGL-5 [Gal- $\alpha 1,3-G a l-\alpha 1,6$ (Fuc- $\alpha 1,2)$-Gal- $\beta 1,6-$ Man- $\alpha 1,2-$ Ins-P-Cer] (Fig. 1). The stimulation ability of AGLs in $\mathrm{T}$ cells was reported. ${ }^{10)}$ To determine the stimulation of AGLs in $i \mathrm{NKT}$ cells, we confirmed that AGLs activated $i \mathrm{NKT}$ cells to induce IL-2 release in a CD1d-dependent manner and compared the ability of $\alpha$-GalCer and iGb3 with each AGL in terms of IL-2 release (Fig. 2). AGLs presented by RBLCD1d cells induced IL-2 release from $i$ NKT cells as well as $\alpha$-GalCer and iGb3, although the co-cultivation of $i \mathrm{NKT}$

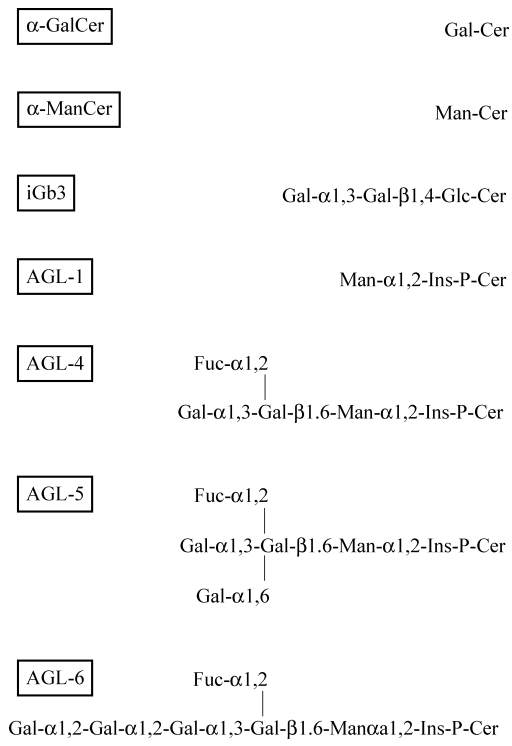

Fig. 1. Structure of the Glycosphingolipids (GSLs) and Acidic Glycosphingolipids (AGLs) of Edible Mushrooms

AGLs were isolated from total GSL fraction of H. marmoreus (T-H.m.) or P. eryngii (T-P.e.). AGL-1H, AGL-4 and AGL-6 were isolated from T-H.m., and AGL-1P and AGL-5 were isolated from T-P.e. All AGLs have an inositolphosphoceramide (Ins-PCer) as the core structure. Abbreviations: $\alpha$-GalCer, alpha-galactosylceramide; $\alpha$ ManCer, alpha-mannosylceramide; AGL, acidic glycosphingolipid, Cer, ceramide; Fuc, fucose; Gal, galactose; Glc; glucose; iGb3, isoglobotrihexosylceramide; Ins, inositol; Man, mannose.

cells with any AGLs and RBL cells did not induce IL-2 release. AGLs were weaker antigens for $i$ NKT cells than $\alpha$ GalCer, although almost all AGLs had a greater or equal capacity than iGb3. Additionally, AGL-1 induced IL-2 release from $i \mathrm{NKT}$ cells in a CD1d-dependent manner. IL-2 release was detected from the co-cultivation of $i$ NKT cells with RBL cells and $\alpha$-GalCer in spite of being lower than that of RBLCD1d cells. This result suggested that CD1d expressed on $i$ NKT cells is directly involved in presenting $\alpha$-GalCer as well as the previous report. ${ }^{12)}$

It was indicated that CD1d-restricted presentation of AGLs could stimulate $i$ NKT cells (Fig. 2). We previously reported that AGL stimulation induced both IFN- $\gamma$ and IL-4 release from murine T cells as well as $\alpha$-GalCer. ${ }^{10)}$ Dendritic cells (DCs) have an organ-specific aspect: thymic DCs are unique APCs because of their role in generating central $\mathrm{T}$ cell tolerance through the negative selection of autoreactive thymocytes ${ }^{5)}$; therefore, to confirm the induction of Th1/Th2 cytokine release from $i$ NKT cells by AGLs and to compare the antigen-presentation pattern between splenic and thymic DCs, cytokine release from $i$ NKT cells was investigated by stimulating CD11c-positive cells and $1 \mu \mathrm{g} / \mathrm{ml}$ AGLs (Fig. 3). Slight IFN- $\gamma$ release from $i$ NKT cells was detected with some AGLs between splenic and thymic CD11c-positive cells, but obvious IL-4 release was detected with all AGLs both splenic and thymic CD11c-positive cells. AGL-1 presented by CD11c-positive cells also stimulated $i$ NKT cells in spite of weak stimulation. Moreover, it was observed that the different magnitude of IL- 4 release from $i$ NKT cells by stimulating of AGL- $1 H$, AGL-4 and AGL-5 between splenic and thymic CD11c-positive cells. IL-4 releases with AGL- $1 H$ and AGL-4 presented splenic CD11c-positive cells were higher than that of thymocytes, meanwhile, AGL-5 presented 


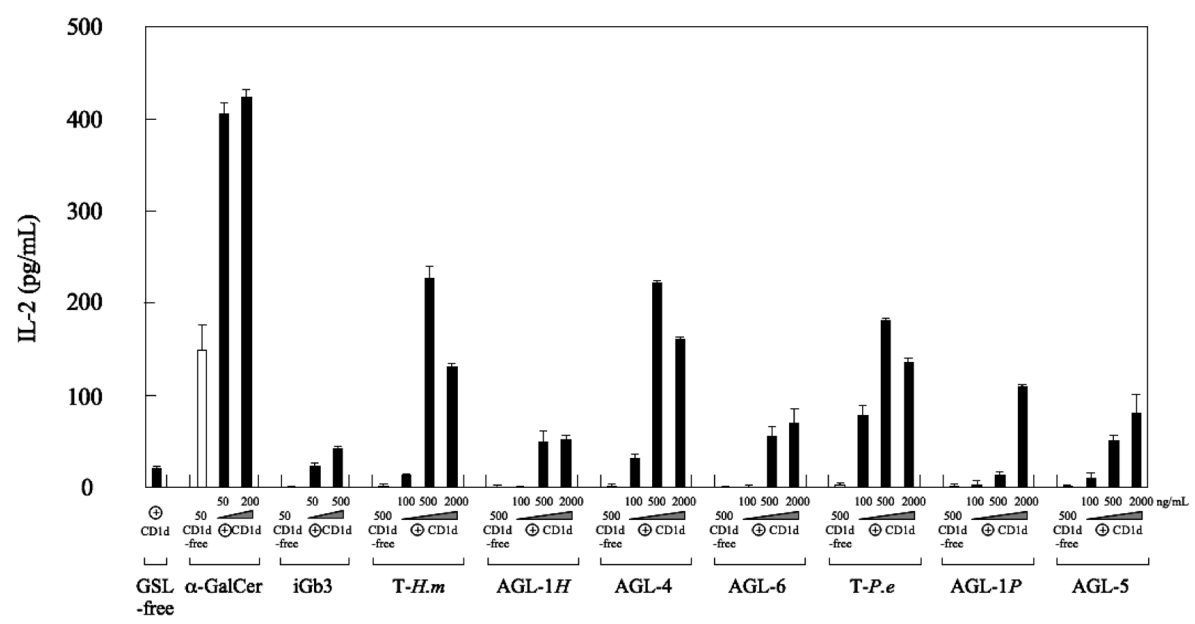

Fig. 2. IL-2 Release from $i$ NKT Hybridoma Cells by Stimulation with GSLs and AGLs

V $\alpha 14-\mathrm{J} \alpha 18$ invariant NKT hybridoma cells were stimulated by GSLs and various AGLs in the presence of RBL cells or CD1d-RBL cells. In each treatment of GSL antigen, the leftmost bar represents the result of RBL cells and $i$ NKT cells in the presence of GSL antigen $(\alpha$-GalCer: $50 \mathrm{ng} / \mathrm{ml}$, iGb3: $50 \mathrm{ng} / \mathrm{ml}$, AGLs: $500 \mathrm{ng} / \mathrm{ml})$, meanwhile, the other bars represent the results of CD1d-RBL and $i \mathrm{NKT}$ cells $(\alpha$-GalCer: 50 or $200 \mathrm{ng} / \mathrm{ml}$, iGb3: 50 or $500 \mathrm{ng} / \mathrm{ml}$, AGLs: 100, 500 or $2000 \mathrm{ng} / \mathrm{ml})$. Mean \pm S.D. of duplicate samples is shown; data are representative of two independent experiments.
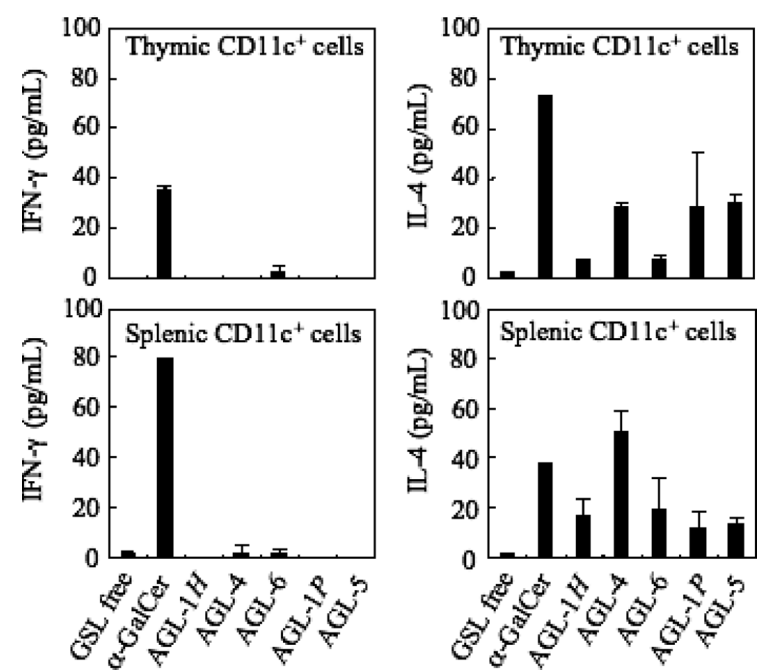

Fig. 3. Cytokine Release from $i$ NKT Hybridoma Cells by Stimulation of CD11c-Positive Cells with AGLs and GSLs

The $i$ NKT hybridoma cells were stimulated by various AGL $(1000 \mathrm{ng} / \mathrm{ml})$ and GSLs $(\alpha$-GalCer: $100 \mathrm{ng} / \mathrm{ml})$ in the presence of splenic CD11c-positive cells or thymic CD11c-positive cells. Mean \pm S.D. of duplicate samples is shown; data are representative of two independent experiments.

thymic CD11c-positive cells induced more IL-4 release than that of splenocytes as well as that of $\alpha$-GalCer. This result indicated that AGLs induce IL-4 release from $i$ NKT cells.

CD1d is expressed on B cells as well as DCs, and $\alpha$-GalCer-pulsed B cells selectively elicit weak IL-4 release from NKT cells, although only DCs efficiently activate $i$ NKT cells when $\alpha$-GalCer was injected. ${ }^{15)}$ To confirm whether AGLs are presented by B cells to stimulate $i$ NKT cells, cytokine release from $i$ NKT cells was investigated by B cells and $1 \mu \mathrm{g} / \mathrm{ml}$ of AGLs (Fig. 4). By comparison with GSL antigenfree, IFN- $\gamma$ release was not detected with any AGL. But AGL-1s and total AGL fractions (T-H.m and T-P.e) induced IL-4 release from $i$ NKT cells; however, other antigens did not. B cells presenting $\alpha$-GalCer can induce anergy in $i \mathrm{NKT}$ cells whereas DCs do not ${ }^{15,16)}$; therefore, it was predicted that $i$ NKT cells stimulated by B cells presenting AGL-1 do not release IL-2. AGL-1 presented by B cells induced IL-4 re-
A)
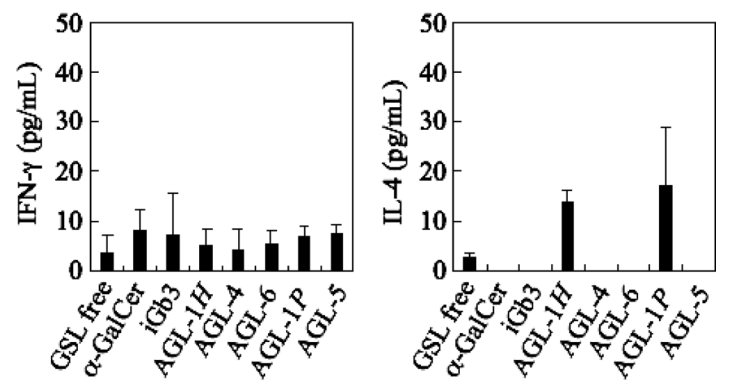

B)

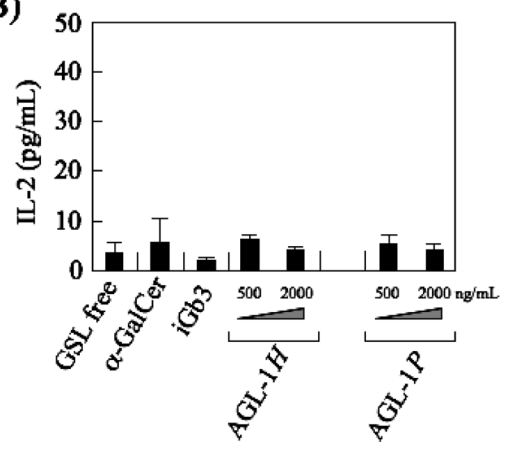

Fig. 4. Cytokine Release from $i$ NKT Hybridoma Cells by Stimulation of B Cells with AGLs and GSLs

(A) IFN- $\gamma$ and IL-4 release from $i$ NKT hybridoma cells by stimulation of B cells with GSLs and AGLs. The $i$ NKT hybridomas were stimulated by GSLs $(\alpha$-GalCer: $100 \mathrm{ng} / \mathrm{ml}, \mathrm{iGb} 3: 500 \mathrm{ng} / \mathrm{ml})$ and various AGLs $(2000 \mathrm{ng} / \mathrm{ml})$ in the presence of B cells. (B) The induction of IL-2 release from $i$ NKT hybridoma cells by stimulation with GSLs ( $\alpha$-GalCer: $100 \mathrm{ng} / \mathrm{ml}$, iGb3: $500 \mathrm{ng} / \mathrm{ml}$ ) and AGLs (AGL- $1 H$ and AGL-1P: 500 or $2000 \mathrm{ng} / \mathrm{ml}$ ). Mean \pm S.D. of duplicate samples is shown; data are representative of two independent experiments.

lease from $i$ NKT cells but IL-2 was not detected; nevertheless, AGL-1 was applied at $2 \mu \mathrm{g} / \mathrm{ml}$. Although it is uncertain what does not lead $\mathrm{B}$ cells to induce IL-2 release from $i \mathrm{NKT}$ cells, this result indicated that B cells presenting AGL-1 induce an absolute Th2 shift of $i$ NKT cells.

Administration of AGLs Induced Elevation of $\mathbf{C y}$ tokine Release Into Sera Since it was indicated that AGLs could stimulate $i \mathrm{NKT}$ cells to release IL-4, we investigated Th1/Th2 cytokine levels in serum after intravenous AGLs in- 
A)

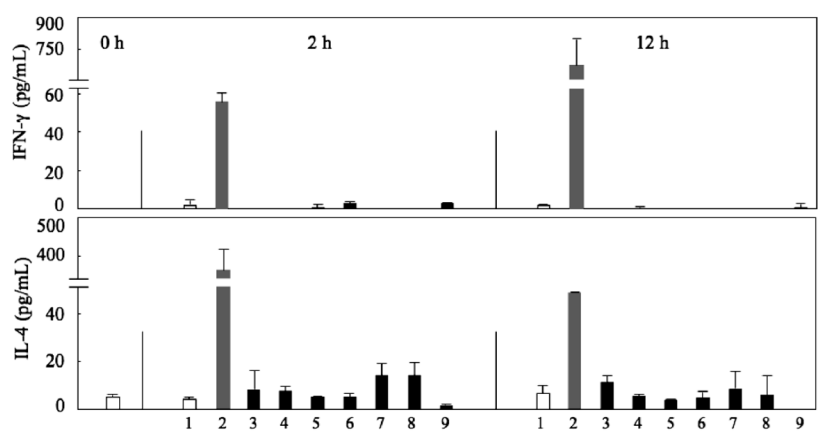

B)
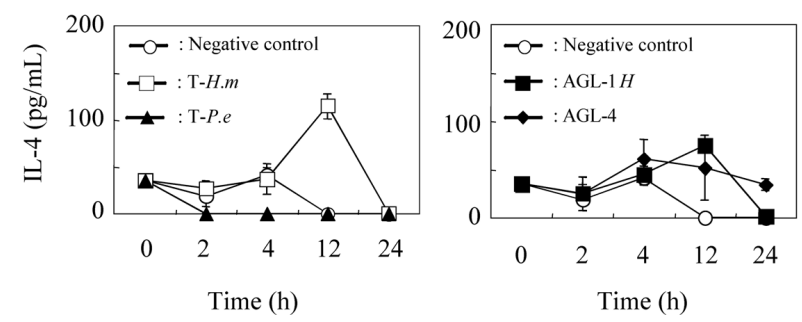

Fig. 5. Serum IFN- $\gamma$ and IL-4 in Mice Treated with AGLs

(A) AGLs $(20 \mathrm{mg})$ or $\alpha$-GalCer $(0.5 \mu \mathrm{g})$ were injected intravenously into naive mice and serum IFN- $\gamma$ and IL-4 was measured 2 and $12 \mathrm{~h}$ after injection. Lane 1, Negative control: lane 2, with $\alpha$-GalCer: lane 3, with T-H.m: lane 4, with AGL-1H: lane 5, with AGL-4: lane 6, with AGL-6: lane 7, with T-Pe: lane 8, with AGL-1P: lane 9, with AGL-5. (B) Repeated intravenous injection of AGLs $(10 \mu \mathrm{g})$ into mice was performed $24 \mathrm{~h}$ after the first injection $(10 \mu \mathrm{g})$ and serum IL-4 was measured at the indicated time. Mean \pm S.D. of duplicate samples is shown; data are representative of two independent experiments.

jection and compared the ability of $\alpha$-GalCer (Fig. 5). A single AGLs injection induced IL-4 elevation but not IFN- $\gamma$ as well as an in vitro response, even when IL-4 level was lower. The secondary immune response to $\alpha$-GalCer of NKT cells, as compared with the primary response to this antigen, is typically blunted ${ }^{16)}$; moreover, repeated $\alpha$-GalCer injection changes the cytokine profile of $i$ NKT cells to a Th2 bias. ${ }^{17}$ We hypothesized that consumed edible mushroom AGLs stimulate $i$ NKT cells continuously. To confirm the cytokine profile in serum by continuous stimulation with AGLs, IFN- $\gamma$ and IL-4 were investigated after a second intravenous AGLs injection and compared with a single injection (Fig. 5). Although total injected amount of AGLs was same between single and repeated challenge, repeated AGLs injection induced a greater IL-4 elevation than a single injection in spite of delayed elevation. But IFN- $\gamma$ was not detected (data not shown). The IL-4 induced by repeated injection of T-H.m and AGL-1 peaked at $12 \mathrm{~h}$, and IL-4 elevation by T-H.m depended on AGL-1 because IL-4 was detected by repeated injection of AGL-4 at $24 \mathrm{~h}$ though that of T-H.m was not detected completely. Repeated AGL-4 injection induced a prolonged rather than delayed IL-4 elevation, but repeated AGL-1 injections did not induce a prolonged IL-4 elevation. Single AGL-6 injection induced IL-4 elevation but repeated one did not induce IL-4 elevation (data not shown). Both single and repeated injection of AGL-5 did not induce IL-4 elevation. Although T-P.e contains AGL-1, intravenous T-P.e injection did not induce IL-4 elevation.

\section{DISCUSSION}

$i$ NKT cells are unique T lymphocytes in terms of the conservation of their specificity and activated phenotype; this suggests that studies elucidating key components of mouse $i$ NKT cell biology will likely also prove important for human $i$ NKT cells. ${ }^{18)}$ This study confirmed that edible mushroom AGLs (Fig. 1) activate $i$ NKT cells in the same CD1d-dependent manner as $\alpha$-GalCer and iGb3 (Fig. 2). AGLs were weaker antigens than $\alpha$-GalCer but were similar to iGb3 when stimulated at $500 \mathrm{ng} / \mathrm{ml}$, in terms of IL-2 release (Fig. 2). The Gal- $\alpha 1,2-$ GalCer, Gal- $\alpha 1,4-G a l C e r$ or iGb4 must be processed in APCs to the corresponding $\alpha$-GalCer or iGb3 for stimulation of $i \mathrm{NKT}$ cells, ${ }^{14)}$ but Gal- $\alpha 1,6-$ GalCer stimulates $i$ NKT cells without antigen processing compared to $\alpha$ GalCer. ${ }^{14)}$ RBL-CD1d cells induce IL-2 release from $i$ NKT cells with antigen processing, and IL-2 release from $i$ NKT cells by processed GSL antigens was lower than that of GSL antigens without antigen processing. ${ }^{14)}$ On the other hand, $i$ NKT cells recognize intact tetrasaccharide-containing GSL antigen containing $\alpha$-1,2-linked Man as a non-reducing end. ${ }^{19)}$ Therefore, it was suggested that AGL-6 was processed to stimulate $i$ NKT cells to the corresponding AGL-4 though AGL-1, AGL-4 and AGL-5 could stimulate $i$ NKT cells without antigen processing (Figs. 2, 3); however, it is uncertain which non-reducing terminal sugar of AGL-5 is recognized by $i$ NKT cells because AGL-5 has two potential terminal sugars. ${ }^{10)}$ The difference in induced IL-2 release between AGL- $1 H$ and AGL-1P suggested that the non-hydroxyl fatty acid of Ins-P-Cer structure might be involved because AGL$1 P$ contains non-hydroxyl fatty acid. ${ }^{10)}$ Moreover, AGL-1 presented by B cells induced IL-4 release from $i$ NKT cells as well as CD11c-positive cells (Fig. 4). Although the CD1d-restricted recognition of mannosylated lipids by $i$ NKT cells has been reported, ${ }^{19-22)}$ the natural occurrence of mannosylated lipid has not been reported in mammals; therefore, it was suggested that recognition of mannosylated lipid by $i$ NKT cells might be involved in recognizing foreign invasion.

A single $\alpha$-GalCer injection into mice activates $i$ NKT cells to produce IFN- $\gamma$, resulting in protective immune responses against pathogens and tumors. ${ }^{4)}$ By contrast, repeated $\alpha$-GalCer injection changes the cytokines profiles of $i$ NKT cells so that only IL- 10 , but not IFN- $\gamma$, is produced. ${ }^{17)}$ The $\alpha$-GalCer administration induces $i$ NKT cell proliferation, but $i$ NKT cell anergy occurs after their proliferation. ${ }^{23,24)}$ Not only anergy but also apoptosis of $i$ NKT cells is induced after $\alpha$-GalCer injection because of the avoidance of excessive inflammation. ${ }^{16)} i \mathrm{NKT}$ cell anergy is in common with that of conventional T cells, but IL-2 overcomes $i \mathrm{NKT}$ cell anergy and has a beneficial effect on repeated $\alpha$-GalCer administration. ${ }^{16)}$ On the other hand, it was reported that IL-4 might be a growth factor in $\alpha$-GalCer-induced $i$ NKT cell expansion, whereas IFN- $\gamma$ tends to inhibit this proliferation ${ }^{25)}$; therefore, as it has been suggested that repeated administration of weaker compounds is effective to avoid anergy and the necessity of developing glycolipid-containing adjuvants to stimulate $i$ NKT cells, ${ }^{18)}$ we presumed that edible mushroom AGLs might correspond to the described materials (Figs. 2, 3, 5). ${ }^{10)}$ Moreover, the recognition of Th1 or Th2 cytokines by DCs acts as a negative feedback loop to maintain Th1/Th2 cytokine balance through NKT cell function ${ }^{26}$; 
therefore it was suggested that IL-4 release from $i$ NKT cells by AGLs (Figs. 3, 5) may contribute to maintain the environment to induce a Th1 response through $\mathrm{Th} 1 / \mathrm{Th} 2$ negative feedback loop.

Positive selection by endogenous GSL antigens in the thymus is indispensable to NKT cells, ${ }^{5,6)}$ but endogenous GSL antigen is unknown. It has been suggested that GSL storage might result in alterations in the thymic selection of $i \mathrm{NKT}$ cells $^{27)}$; however, CD1d expression was not substantially altered in the multiple GSL storage models mice and there were only subtle differences in APC frequencies between GSL storage models and controls in the thymus. ${ }^{27)}$ We propose that AGL administration might play a role in symptomatic therapy to recover the reduced percentage and frequency of $i$ NKT cells.

This study indicates that edible mushroom AGLs induce cytokine release from $i$ NKT cells in a CD1d-dependent manner in vitro and in vivo. Since per capita sphingolipid consumption in the U.S.A. can be estimated to be on the order of $0.3-0.4 \mathrm{~g} / \mathrm{d},{ }^{28)}$ and that not only injection but also oral intake of $\alpha$-GalCer analogue induced suppression of experimental autoimmune encephalomyelitis by induction of predominant IL-4 production, ${ }^{29)}$ we speculate that mushroom AGLs consumed orally might be involved in the maintenance of immunohomeostasis through $i$ NKT cell activation.

Acknowlegements This study was supported in part by Grants-in-Aid for Regional R\&D Proposal-Based Program from Northern Advancement Center for Science \& Technology of Hokkaido Japan, and in part by a Grant-in-Aid from the Ministry of Education, Culture, Sports, Science and Technology of Japan (17405041).

\section{REFERENCES AND NOTES}

1) Present address: Research Center for Medical Glycoscience, National Institute of Advanced Industrial Science and Technology (AIST); Umezono, Tsukuba, Ibaraki 305-8568, Japan.

2) Kawano T., Cui J., Koezuka Y., Toura I., Kaneko Y., Motoki K., Ueno H., Nakagawa R., Sato H., Kondo E., Koseki H., Taniguchi M., Science, 278, 1626-1629 (1997).

3) Brossay L., Chioda M., Burdin N., Koezuka Y., Casorati G., Dellabona P., Kronenberg M., J. Exp. Med., 188, 1521-1528 (1998).

4) Fujii S., Shimizu K., Smith C., Bonifaz L., Steinman R. M., J. Exp. Med., 198, 267-279 (2003).

5) Savage P. B., Teyton L., Bendelac A., Chem. Soc. Rev., 35, 771-779 (2006).

6) Godfrey D. I., Berzins S. P., Nat. Rev. Immunol., 7, 505-518 (2007).

7) Uezu K., Kawakami K., Miyagi K., Kinjo Y., Kinjo T., Ishikawa H., Saito A., J. Immunol., 172, $7629-7634$ (2004).
8) Jennemann R., Bauer B. L., Bertalanffy H., Geyer R., Gschwind R. M., Selmer T., Wiegandt H., Eur. J. Biochem., 259, 331-338 (1999).

9) Jennemann R., Geyer R., Sandhoff R., Gschwind R. M., Levery S. B., Gröne H. J, Wiegandt H., Eur. J. Biochem., 268, 1190-1205 (2001).

10) Nozaki H., Itonori S., Sugita M., Nakamura K., Ohba K., Suzuki A., Kushi Y., Biochem. Biophys. Res. Commun., 373, 435- 439 (2008).

11) Thedrez A., de Lalla C., Allain S., Zaccagnino L., Sidobre S., Garavaglia C., Borsellino G., Dellabona P., Bonneville M., Scotet E., Casorati G., Blood, 110, 251-258 (2007).

12) Nyambayar D., Iwabuchi K., Hedlund E., Murakawa S., Shirai K., Iwabuchi C., Kon Y., Miyazaki Y., Yanagawa Y., Onoé K., J. Clin. Exp. Hematop., 47, 1-8 (2007).

13) Itonori S., Yamawaki S., Aoki K., Yamamoto K., Hada N., Takeda T., Dulaney J. T., Sugita M., Glycobiology, 18, 540-548 (2008).

14) Saqgiv Y., Bai L., Wei D. G., Agami R., Savage P. B., Teyton L., Bendelac A., J. Exp. Med., 204, $921-928$ (2007).

15) Schmieg J., Yang G., Franck R. W., Van Rooijen N., Tsuji M., J. Immunol., 174, 4696-4705 (2005).

16) Parekh V. V., Wilson M. T., Olivares-Villagómez D., Singh A. K., Wu L., Wang C. R., Joyce S., Van Kaer L., J. Clin. Invest., 115, 2572 2583 (2005).

17) Kojo S., Seino K., Harada M., Watarai H., Wakao H., Uchida T., Nakayama T., Taniguchi M., J. Immunol., 175, 3648-3655 (2005).

18) Sullivan B. A., Kronenberg M., J. Clin. Invest., 115, 2328-2329 (2005).

19) Kinjo Y., Pei B., Bufali S., Raji R., Richardson S. K., Imamura M., Fujio M., Wu D., Khurana A., Kawahara K., Wong C. H., Howell A. R., Seeberger P. H., Kronenberg M., Chem. Biol., 15, 654-664 (2008).

20) Fischer K., Scotet E., Niemeyer M., Koebernick H., Zerrahn J., Maillet S., Hurwitz R., Kursar M., Bonneville M., Kaufmann S. H., Schaible U. E., Proc. Natl. Acad. Sci. U.S.A., 101, 10685-10690 (2004).

21) Sidobre S., Hammond K. J., Bénazet-Sidobre L., Maltsev S. D., Richardson S. K., Ndonye R. M., Howell A. R., Sakai T., Porcelli G. S., Kronenberg M., Proc. Natl. Acad. Sci. U.S.A., 101, 12254-12259 (2004).

22) Zajonc D. M., Ainge G. D., Painter G. F., Severn W. B., Wilson I. A., J. Immunol., 177, 4577-4583 (2006).

23) Wilson M. T., Johansson C., Olivares-Villagómez D., Singh A. K., Stanic A. K., Wang C. R., Joyce S., Wick M. J., Van Kaer L., Proc. Natl. Acad. Sci. U.S.A., 100, 10913-10918 (2003).

24) Crowe N. Y., Uldrich A. P., Kyparissoudls K., Hammond K. J., Hayakawa Y., Sidobre S., Keating R., Kronenberg M., Smyth M. J., Godfrey D. I., J. Immunol., 171, 4020-4027 (2003).

25) Iizuka A., Ikarashi Y., Yoshida M., Heike Y., Takeda K., Quinn G., Wakasugi H., Kitagawa M., Takaue Y., Immunology, 123, 100-107 (2008).

26) Minami K., Yanagawa Y., Iwabuchi K., Shinohara N., Harabayashi T., Nonomura K., Onoé K., Blood, 106, 1685-1693 (2005).

27) Gadola S. D., Silk J. D., Jeans A., Illarionov P. A., Salio M., Besra G. S., Dwek R., Butters T. D., Platt F. M., Cerundolo V., J. Exp. Med., 203, 2293-2303 (2006).

28) Vesper H., Schmeiz E. M., Nikolova-Karakashian M. N., Lynch D. L., Merrill A. H. Jr., J. Nutr., 129, 1239-1250 (1999).

29) Miyamoto K., Miyake S., Yamamura T., Nature (London), 413, 531534 (2001). 